Volume : 6

Nomor : 4

Bulan : November

Tahun : 2020

E-ISSH: 2656-940X

P-ISSH: 2442-367K

URL: jurnal.ideaspublishing.co.id

\title{
Meningkatkan Aktivitas dan Hasil Belajar Siswa Melalui Model Pembelajaran Kooperatif Tipe Two Stay Two Stray pada Mata Pelajaran Ekonomi Kelas XI IPS 2 di SMA Negeri 1 Tapa
}

\author{
Miranda Puspita Sari \\ Ismail Raflin Hinelo \\ Agil Bahsoan
}

Program Studi S1 Pendidikan Ekonomi, Universitas Negeri Gorontalo

Pos-el: mirandaismail535@gmail.com

\section{DOI: 10.32884 /ideas.v6i4.303}

\begin{abstract}
Abstrak
Tujuan penelitian ini adalah untuk meningkatkan aktivitas dan hasil belajar siswa pada mata pelajaran Ekonomi kelas XI IPS 2 di SMA Negeri 1 Tapa melalui model pembelajaran kooperatif tipe two stay two stray. Metode penelitian yang digunakan adalah metode penelitian tindakan kelas. Sampel penelitian adalah siswa kelas XI IPS 2 yang berjumlah 32 siswa. Teknik pengumpulan data adalah wawancara, observasi, tes aktivitas belajar, tes hasil belajar, dan dokumentasi. Penelitian dilaksanakan dengan 2 siklus. Teknik analisis data digunakan kuantitatif deskriptif. Kesimpulan dari penelitian ini adalah terdapat peningkatan aktivitas dan hasil belajar siswa pada mata pelajaran Ekonomi kelas XI IPS 2 di SMA Negeri 1 Tapa dibuktikan dari meningkatnya jumlah siswa yang aktif pada observasi awal 8 siswa (25\%) menjadi 23 siswa (72\%) pada siklus I, kemudian meningkat menjadi 28 siswa (88\%) pada siklus II. Jumlah siswa yang memperoleh nilai $\geq 75$ pada observasi awal 9 siswa $(28 \%)$ menjadi 24 siswa (75\%) pada siklus I, kemudian meningkat menjadi 28 siswa (88\%) pada siklus II. Dengan demikian, hipotesis penelitian yang berbunyi "Jika guru menggunakan model pembelajaran kooperatif tipe two stay two stray, maka aktivitas dan hasil belajar siswa pada mata pelajaran Ekonomi kelas XI IPS 2 di SMA Negeri 1 akan meningkat" dapat diterima karena terbukti kebenarannya.
\end{abstract}

\section{Kata kunci}

Two stay two stray, aktivitas belajar, hasil belajar

\section{Abstract}

The purpose of this study was to increase student activity and learning outcomes in the subjects of Economics class XI IPS 2 at SMA Negeri 1 Tapa through the two stay two stray type of cooperative learning model. The research method used is a classroom action research method. The research sample was students of class XI IPS 2, totaling 32 students. Data collection techniques are interviews, observation, learning activity tests, learning outcomes tests, and documentation. The research was conducted in 2 cycles. The data analysis technique used descriptive quantitative. The conclusion of this study is that there is an increase in activity and student learning outcomes in Economics class XI IPS 2 at SMA Negeri 1 Tapa as evidenced by the increase in the number of active students in the initial observation of 8 students (25\%) to 23 students (72\%) in the cycle. I, then increased to 28 students (88\%) in cycle II. The number of students who scored $\geq 75$ in the initial observation was 9 students (28\%) to 24 students (75\%) in cycle I, then increased to 28 students (88\%) in 
cycle II. Thus, the research hypothesis which reads "If the teacher uses the cooperative learning model type two stay two stray, then the activity and student learning outcomes in Economics class XI IPS 2 at SMA Negeri 1 will increase" can be accepted because it is proven to be true.

Keywords

Two stay two stray, learning activities, learning outcomes

\section{Pendahuluan}

Aktivitas belajar merupakan salah satu aspek yang sangat penting dalam pembelajaran. Pembelajaran yang menekankan aktivitas belajar lebih bermakna dan membawa siswa pada pengalaman belajar yang mengesankan. Aktivitas belajar merangsang siswa terlibat secara aktif dalam pembelajaran, sehingga dapat merangsang otak siswa agar dapat berpikir kritis serta memecahkan permasalahan.

Seorang pakar pendidikan, Trinandita (1984) menyatakan bahwa hal mendasar yang dituntut dalam proses pembelajaran adalah keaktifan siswa. Keaktifan siswa dalam proses pembelajaran akan menyebabkan interaksi yang tinggi antara guru dengan siswa ataupun dengan siswa itu sendiri. Hal ini akan mengakibatkan suasana kelas menjadi segar dan kondusif. Masing-masing siswa dapat melibatkan kemampuannya semaksimal mungkin.

Aktivitas belajar merupakan asas yang terpenting dalam proses belajar karena belajar merupakan suatu kegiatan yang bersifat jasmani maupun rohani. Tanpa kegiatan tidak mungkin seseorang dapat belajar (Nasution, 2012: 86). Oleh karena itu, siswa harus diberi kesempatan untuk melakukan kegiatan atau beraktivitas. Kegiatan siswa merupakan kegiatan atau perilaku yang terjadi selama proses pembelajaran. Aktifnya siswa selama proses pembelajaran merupakan salah satu indikator adanya keinginan atau motivasi siswa untuk belajar. Siswa dikatakan memiliki keaktifan apabila ditemukan ciri-ciri perilaku seperti: sering bertanya kepada guru atau siswa lain, mau dan mampu mengemukakan pendapat, mampu menjawab pertanyaan, dapat bekerja sama, dapat menghargai pendapat teman. Serta bertanggung jawab terhadap tugas yang diberikan. Dengan demikian, aktivitas yang timbul melalui keaktifan siswa pada proses pembelajaran akan mengakibatkan pula terbentuknya pengetahuan dan keterampilan yang akan mengarah pada peningkatan hasil belajar siswa.

Hasil belajar adalah kemampuan-kemampuan yang dimiliki seorang siswa setelah ia menerima pengalaman belajarnya (Sudjana, 2013:22). Mengetahui hasil dari proses belajar siswa, maka seorang guru dapat menentukan kedudukannya dalam kelas, apakah siswa tersebut termasuk ke dalam kategori siswa yang pandai, sedang, atau kurang. 


\section{Volume : 6 \\ Nomor : 4 \\ Bulan : November \\ Tahun : 2020}

E-ISSH: 2656-940X

P-ISSH: 2442-367K

URL: jurnalideaspublishing.co.id

Dari beberapa pendapat mengenai aktivitas dan hasil belajar siswa dapat disimpulkan bahwa dalam proses pembelajaran dapat memberikan pengalaman belajar yang bermakna bagi siswa, sehingga materi pelajaran yang disampaikan dapat dipahami oleh siswa dengan baik, serta dapat membantu siswa untuk meningkatkan hasil belajarnya. Sedangkan siswa yang cenderung kurang melakukan aktivitas atau pasif, maka hasil belajar yang diperoleh lebih rendah dari siswa yang berpartisipasi aktif dalam pembelajaran.

Upaya yang harus dilakukan guru sebagai tenaga pendidik dalam meningkatkan aktivitas serta hasil belajar siswa adalah penggunaan model pembelajaran kooperatif. Sejalan dengan yang dinyatakan oleh Suprijono (2013: 54) bahwa pembelajaran kooperatif merupakan jenis kerja kelompok termasuk bentuk-bentuk kegiatan yang dibimbing dan diarahkan oleh guru. Pembelajaran kooperatif mengutamakan kerja sama dalam menyelesaikan permasalahan untuk menerapkan pengetahuan dan keterampilan dalam rangka mencapai tujuan pembelajaran.

Salah satu model pembelajaran kooperatif yang digunakan dalam penelitian ini adalah model pembelajaran kooperatif tipe two stay two stray. Berdiati (2010: 92) mengemukakan bahwa model pembelajaran kooperatif tipe two stay two stray adalah model pembelajaran dua tinggal dua bertamu merupakan bagian dari pembelajaran kooperatif yang memberi pengalaman kepada siswa untuk berbagi pengetahuan, baik di dalam kelompok maupun di kelompok lainnya. Siswa dituntut berperan secara aktif dalam diskusi berkelompok untuk memecahkan suatu masalah secara bersama-sama dengan teman sekelompoknya. Hasil dari diskusi kelompok akan dicocokkan dengan jawaban kelompok lain yang diperoleh dari teman mereka yang bertamu ke kelompok lain.

Berdasarkan hasil observasi selama pelaksanaan Praktik Pengalaman Lapangan (PPL) pada bulan September-Oktober 2019 di kelas XI IPS 2 SMA Negeri 1 Tapa pada mata pelajaran Ekonomi, peneliti menemukan beberapa masalah pada proses pembelajaran. Proses pembelajaran yang berlangsung di SMA Negeri 1 tapa khususnya kelas XI IPS 2 menerapkan model pembelajaran yang sama pada setiap pembelajaran khususnya mata pelajaran Ekonomi. Sehingga siswa merasa bosan dan mengalihkan kebosanannya dengan membuat kegaduhan, bercerita dengan siswa lainnya, dan tidak memperhatikan guru yang sedang mengajar. Masih banyak siswa yang kurang berperan aktif dalam proses pembelajaran dilihat dari kurangnya siswa yang bertanya, menjawab pertanyaan, mengemukakan pendapat, menghargai pendapat teman, serta bertanggung jawab terhadap tugas yang diberikan. Hal ini akan berdampak pada 
hasil belajarnya, karena bisa dikatakan bahwa jika tidak adanya kegiatan siswa dalam pembelajaran, maka kurangnya pemahaman siswa terhadap materi pelajaran yang disampaikan. Hal tersebut disebabkan oleh penggunaan model pembelajaran yang kurang bervariatif dan monoton sehingga membuat pembelajaran menjadi terasa membosankan.

Berdasarkan pengambilan data aktivitas belajar siswa kelas XI IPS 2 yang dilakukan oleh peneliti, terlihat bahwa sebagian besar siswa di kelas XI IPS 2 kurang berperan aktif dalam pembelajaran. Dari jumlah siswa 32 orang terdapat $25 \%$ (8 siswa) yang aktif dan $75 \%$ (24 siswa) yang kurang aktif dalam proses pembelajaran. Sedangkan hasil belajar siswa dari jumlah 32 siswa, terdapat $72 \%$ atau sebanyak 23 siswa dibawah standar KKM dan hanya 9 siswa atau $28 \%$ yang mampu mencapai nilai ketuntasan. Hal ini menunjukkan bahwa siswa kelas XI IPS 2 belum bisa mencapai KKM yang telah ditetapkan disekolah yaitu 75 .

Melalui model pembelajaran kooperatif tipe two stay two stray, diharapkan aktivitas dan hasil belajar siswa dapat meningkat. Dilihat dari kegiatan siswa bekerja sama dengan kelompok untuk mendiskusikan masalah, saling berbagi pendapat dan menerima informasi dari anggota kelompok lain serta dapat membantu siswa untuk memahami materi pelajaran yang dibahas. Hasil belajar siswa pada akhir kegiatan pembelajaran akan dinilai melalui evaluasi seputar materi yang telah dipelajari. Hal ini bertujuan untuk mengukur sampai di mana pemahaman siswa setelah melakukan proses belajar.

\section{Aktivitas Belajar}

Aktivitas belajar adalah kegiatan belajar yang dilakukan dalam proses interaksi belajar mengajar dalam rangka mencapai tujuan belajar. Aktivitas belajar yang dimaksud adalah kegiatan siswa dalam menerima pelajaran yang disampaikan oleh guru. Dalam belajar sangat diperlukannya aktivitas, keberhasilan belajar tidak akan tercapai dengan baik tanpa adanya aktivitas belajar. Prinsip belajar adalah berbuat untuk mengubah tingkah laku. Itulah sebabnya aktivitas merupakan prinsip atau asas yang sangat penting dalam interaksi belajar (Sardiman, 2004:95)

Gagne (Abin Syamsudin Makmun, 2003: 105) perubahan perilaku yang merupakan hasil dari aktivitas belajar terdiri dari;

1. Informasi verbal, yaitu penguasaan informasi dalam bentuk verbal, baik secara tulisan maupun lisan. 


\section{Volume : 6 \\ Nomor : 4 \\ Bulan : November \\ Tahun : 2020}

E-ISSH: 2656-940K

P-ISSH: 2442-367K

URL: jurnal.ideaspublishing.co.id

2. Kecakapan intelektual; yaitu keterampilan individu dalam melakukan interaksi dengan lingkungannya dengan menggunakan simbol-simbol.

3. Strategi kognitif; kecakapan individu untuk melakukan pengendalian dan pengelolaan keseluruhan aktivitasnya.

4. Sikap; yaitu hasil pembelajaran yang berupa kecakapan individu untuk memilih macammacam tindakan yang akan dilakukan.

5. Kecakapan motorik; ialah hasil belajar yang berupa kecakapan pergerakan yang dikontrol oleh otot dan fisik.

\section{Hasil Belajar}

Hasil belajar adalah kompensasi atau kemampuan tertentu baik afektif, kognitif, dan psikomotorik yang dicapai atau dikuasai siswa setelah mengikuti proses belajar mengajar (Kunandar, 2014: 62). Sedangkan menurut Hamalik (2009: 30) hasil belajar adalah bila seseorang telah belajar akan terjadi perubahan tingkah laku pada orang tersebut. Perolehan aspek-aspek perubahan perilaku tersebut pada apa yang dipelajari oleh pembelajar.

Permendikbud No. 53 Tahun 2015 mengemukakan bahwa hasil belajar siswa dapat diperoleh dari proses pembelajaran.

1. Ranah Kognitif

Penilaian pengetahuan dilakukan dengan cara mengukur penguasaan siswa yang mencakup pengetahuan faktual, konseptual, dan prosedural dalam berbagai tingkatan proses berpikir. Penilaian ini berfungsi sebagai alat pendeteksi kesulitan belajar, sebagai penilaian proses pembelajaran dan alat untuk mengukur pencapaian dalam proses pembelajaran.

2. Ranah Afektif

Penilaian sikap dimaksudkan sebagai penilaian terhadap perilaku siswa dalam proses pembelajaran kegiatan kurikuler dan ekstrakurikuler, meliputi sikap spiritual dan sosial.

3. Ranah Psikomotorik

Penentuan teknik penilaian didasarkan pada karakteristik kompetensi keterampilan yang hendak diukur, karena tidak semua kompetensi dasar dapat diukur dengan penilaian kinerja, proyek, atau portofolio. Penilaian keterampilan dimaksudkan unutk mengetahui penguasaan pengetahuan peserta didik untuk dapat digunakan dalam mengenal dan menyelesaikan masalah dalam kehidupan sesungguhnya (dunia nyata). 


\section{Model Pembelajaran Two Stay Two Stray}

Model pembelajaran kooperatif tipe two stay two stray dikembangkan oleh Spencer Kagan (1992). Dua tinggal dua tamu ini memberikan kesempatan kepada siswa untuk saling mencari dan memberikan informasi kepada kelompok lain (Shoimin, 2014: 222). Dalam penerapan model ini, siswa dapat bertukar pikiran dan membangun keterampilan sosial seperti mengajukan pertanyaan, serta dapat menggali informasi atau ide-ide baru pada kelompok lain. Hal ini membuat interaksi siswa dengan siswa lainnya dapat berkembang selama proses pembelajaran.

Slavin (Buchari, 2009: 85) mengemukakan bahwa model pembelajaran Two Stay Two Stray (TS-TS) merupakan model pembelajaran yang membuat siswa berkumpul dengan anggota kelompok kecilnya yang beranggotakan empat orang siswa dalam kelompoknya dan dalam struktur heterogen. Setiap anggota memiliki tugas masing-masing, di antaranya yaitu dua siswa bertugas tinggal pada kelompoknya yang nantinya akan memberikan informasi pada tamu dari kelompok lain. Penggunaan model ini dapat meningkatkan rasa sikap tolong menolong antar siswa.

Adapun langkah-langkah yang digunakan dalam pelaksanaan model pembelajaran kooperati tipe two stay two stray (Suprijono 2012: 93) antara lain sebagai berikut.

1. Siswa dibagi menjadi kelompok-kelompok kecil.

2. Masing-masing kelompok diberi tugas berupa permasalahan-permasalahan yang perlu didiskusikan.

3. Setelah diskusi antar kelompok selesai, dua orang dari masing-masing kelompok meninggalkan kelompoknya untuk bertamu kepada kelompok yang lain. Anggota kelompok yang tidak mendapat tugas sebagai tamu (stray) mempunyai kewajiban untuk menerima tamu (stay).

4. Tugas tuan rumah (stay) adalah menyajikan hasil kerja kelompoknya kepada setiap tamu (stray) yang datang, sedangkan dua orang yang bertugas sebagai tamu (stray) diwajibkan bertamu kepada semua kelompok untuk mencari informasi sebanyakbanyaknya tentang materi yang dibahas oleh kelompok tersebut.

5. Jika telah selesai menunaikan tugas, siswa yang berperan (stray) kembali kelompok awal untuk menyampaikan informasi yang didapatkan dari kelompok lain.

6. Mencocokkan dan membahas hasil kerja yang telah ditunaikan. 
Volume : 6

Nomor : 4

Bulan : November

Tahun : 2020

\section{Metode}

Penelitian ini menggunakan jenis Penelitian Tindakan Kelas (PTK) yang difokuskan pada situasi kelas atau yang dikenal dengan Classroom Action Research. Penelitian Tindakan Kelas merupakan suatu pencermatan terhadap kegiatan belajar berupa sebuah tindakan, yang sengaja dimunculkan dan terjadi dalam sebuah kelas secara bersamaan (Suharsimi Arikunto, 2012:3).

Penelitian ini dilaksanakan pada siswa kelas XI IPS 2 di SMA Negeri 1 Tapa dengan jumlah 32 siswa, mulai bulan Oktober 2019 sampai dengan Januari 2020. Prosedur penelitian terdiri dari tahap perencanaan, pelaksanaan, analisis, dan refleksi. Teknik pengumpulan data yaitu observasi, wawancara, tes aktivitas belajar, tes hasil belajar, dan dokumentasi. Teknik analisis data digunakan kuantitatif deskriptif.

\section{Hasil dan Pembahasan}

\section{Hasil}

\section{Siklus I}

Selama proses pelaksanaan tindakan pengajaran siklus I, guru mitra membantu peneliti untuk mengamati segala kegiatan guru dan siswa selama proses pembelajaran berlangsung mulai dari alokasi waktu yang telah disajikan dengan model pembelajaran yang digunakan, serta keaktifan siswa dalam proses pembelajaran. Semua data observasi, aktivitas belajar siswa, dan hasil belajar siswa di akhir siklus I kemudian dianalisis. Berikut hasil analisis siklus I.

Tabel 1 Observasi Kegiatan Guru Siklus I

\begin{tabular}{|c|l|c|c|}
\hline \multirow{2}{*}{ No. } & \multirow{2}{*}{$\begin{array}{c}\text { Kriteria } \\
\text { Aspek }\end{array}$} & \multicolumn{2}{|c|}{ Penilaian } \\
\cline { 3 - 4 } & & Jumlah & $\begin{array}{c}\text { Persentase } \\
(\%)\end{array}$ \\
\hline 1 & Sangat Baik & 8 & $42 \%$ \\
\hline 2 & Baik & 6 & $31 \%$ \\
\hline 3 & Cukup & 3 & $16 \%$ \\
\hline 4 & Kurang & 2 & $11 \%$ \\
\hline \multicolumn{2}{|c|}{ Jumlah } & $\mathbf{1 9}$ & $\mathbf{1 0 0 \%}$ \\
\hline
\end{tabular}


Berdasarkan tabel 1 di atas bahwa hasil observasi dari 19 aspek penilaian kegiatan guru pada siklus I, terdapat 8 aspek yang memperoleh kriteria sangat baik, 6 aspek memperoleh kriteria baik, 3 aspek memperoleh kriteria cukup dan 2 aspek memperoleh kriteria kurang.

Tabel 2 Hasil Observasi Kegiatan siswa Siklus I

\begin{tabular}{|r|l|c|c|}
\hline \multirow{2}{*}{ No. } & \multirow{2}{*}{$\begin{array}{c}\text { Kriteria } \\
\text { Aspek }\end{array}$} & \multicolumn{2}{|c|}{ Penilaian } \\
\cline { 3 - 4 } & & Jumlah & $\begin{array}{c}\text { Persentase } \\
(\%)\end{array}$ \\
\hline 1 & Sangat Baik & 7 & $44 \%$ \\
\hline 2 & Baik & 6 & $38 \%$ \\
\hline 3 & Cukup & 1 & $6 \%$ \\
\hline 4 & Kurang & 2 & $12 \%$ \\
\hline \multicolumn{2}{|c|}{ Jumlah } & $\mathbf{1 6}$ & $\mathbf{1 0 0 \%}$ \\
\hline
\end{tabular}

Berdasarkan tabel 2 di atas bahwa hasil observasi dari 16 aspek penilaian kegiatan siswa pada siklus I, terdapat 7 aspek memperoleh kriteria sangat baik, 6 aspek memperoleh kriteria baik, 2 aspek memperoleh kriteria cukup dan 1 aspek memperoleh kriteria kurang.

Selain data observasi untuk mengamati kegiatan guru dan siswa pada proses pembelajaran, adapun data untuk mengukur keaktifan siswa saat proses pembelajaran berlangsung yang disajikan dalam tabel aktivitas belajar siswa sebagai berikut.

Tabel 3 Analisis Aktivitas Belajar Siswa Siklus I

\begin{tabular}{|c|c|c|c|}
\hline \multirow{2}{*}{ No. } & \multirow{2}{*}{$\begin{array}{c}\text { Kriteria } \\
\text { Aspek }\end{array}$} & \multicolumn{2}{|c|}{ Penilaian } \\
\hline & & Jumlah & $\begin{array}{c}\text { Persentase } \\
(\%)\end{array}$ \\
\hline 1 & Sangat Aktif & 11 & $34 \%$ \\
\hline 2 & Aktif & 12 & $38 \%$ \\
\hline 3 & Cukup Aktif & 9 & $28 \%$ \\
\hline 4 & Kurang Aktif & 0 & $0 \%$ \\
\hline \multicolumn{2}{|c|}{ Jumlah Siswa } & 32 & $100 \%$ \\
\hline
\end{tabular}

Berdasarkan tabel 3 di atas terlihat bahwa dari 32 siswa yang diamati pada siklus I dinilai dari 4 indikator penilaian aktivitas belajar siswa mulai dari kerja sama, keaktifan, sikap menghargai pendapat teman, dan tanggung jawab sebanyak 11 siswa memperoleh kriteria sangat aktif, 12 siswa termasuk kriteria aktif, 9 siswa memperoleh kriteria cukup aktif dan 


\section{Volume : 6 \\ Nomor : 4 \\ Bulan : November \\ Tahun : 2020}

E-ISSH: 2656-940X

P-ISSH: 2442-367X

URL: jurnal.ideaspublishing.co.id

tidak ada siswa yang memperoleh kriteria kurang aktif. Berdasarkan data tersebut masih ada 9 orang siswa yang memperoleh kriteria cukup aktif atau bisa dikatakan masih memiliki kerja sama, keaktifan, sikap menghargai pendapat dan tanggung jawab yang rendah pada proses pembelajaran.

Aktivitas belajar siswa mengalami peningkatan sebesar $43 \%$ yaitu dari observasi $29 \%$ menjadi $72 \%$ setelah dilakukan siklus I. Namun, berdasarkan indikator kerja, persentase tersebut belum mencapai hasil yaitu $85 \%$ sehingga penelitian akan dilanjutkan pada siklus berikutnya atau siklus II.

Data aktivitas belajar di atas menunjukkan bahwa kurangnya keaktifan siswa dalam proses pembelajaran juga akan mempengaruhi hasil belajar siswa. Adapun data hasil belajar siswa pada siklus I sebagai berikut.

Tabel 4 Analisis Hasil Belajar Siswa Siklus I

\begin{tabular}{|c|l|c|c|}
\hline \multirow{2}{*}{ Nilai } & \multirow{2}{*}{$\begin{array}{c}\text { Kriteria } \\
\text { Aspek }\end{array}$} & \multicolumn{2}{|c|}{ Penilaian } \\
\cline { 3 - 4 } & & Jumlah & $\begin{array}{c}\text { Persentase } \\
(\%)\end{array}$ \\
\hline$\leq 75$ & Tidak Tuntas & 8 & $25 \%$ \\
\hline$\geq 75$ & Tuntas & 24 & $75 \%$ \\
\hline \multicolumn{2}{|c|}{ Jumlah Siswa } & $\mathbf{3 2}$ & $\mathbf{1 0 0 \%}$ \\
\hline
\end{tabular}

Tabel 4 di atas menunjukkan bahwa hasil belajar pada siklus I mengalami peningkatan sebesar $43 \%$ yaitu dari observasi awal $32 \%$ menjadi $75 \%$ setelah pelaksanaan tindakan pengajaran pada siklus I.

\section{Siklus II}

Guru mitra dan peneliti pada siklus II bekerja sama untuk mengamati segala kegiatan guru dan siswa selama proses pembelajaran berlangsung mulai dari alokasi waktu yang telah disajikan dengan model pembelajaran yang digunakan, serta keaktifan siswa dalam proses pembelajaran. Di akhir siklus I, semua data observasi, aktivitas belajar siswa, dan hasil belajar siswa dianalisis. Berikut hasil analisis siklus I. 
Volume : 6

Nomor : 4

Bulan : November

URL: jurnal.ideaspublishing.co.id

Tahun : 2020

Tabel 5 Observasi Kegiatan guru Siklus II

\begin{tabular}{|c|l|c|c|}
\hline \multirow{2}{*}{ No. } & \multirow{2}{*}{$\begin{array}{c}\text { Kriteria } \\
\text { Aspek }\end{array}$} & \multicolumn{2}{|c|}{ Penilaian } \\
\cline { 3 - 4 } & & Jumlah & $\begin{array}{c}\text { Persentase } \\
(\%)\end{array}$ \\
\hline 1 & Sangat Baik & 11 & $55 \%$ \\
\hline 2 & Baik & 7 & $35 \%$ \\
\hline 3 & Cukup & 2 & $10 \%$ \\
\hline 4 & Kurang & 0 & $0 \%$ \\
\hline \multicolumn{2}{|r|}{ Jumlah } & $\mathbf{2 0}$ & $\mathbf{1 0 0 \%}$ \\
\hline
\end{tabular}

Berdasarkan tabel 5 di atas bahwa hasil observasi dari 20 aspek penilaian kegiatan guru pada siklus II, terdapat 11 aspek memperoleh kriteria sangat baik, 7 aspek memperoleh kriteria baik, 2 aspek memperoleh kriteria cukup dan tidak ada aspek yang termasuk pada kriteria kurang.

Tabel 6 Hasil Observasi Kegiatan siswa Siklus II

\begin{tabular}{|c|l|c|c|}
\hline \multirow{2}{*}{ No. } & \multirow{2}{*}{$\begin{array}{c}\text { Kriteria } \\
\text { Aspek }\end{array}$} & \multicolumn{2}{|c|}{ Penilaian } \\
\cline { 3 - 4 } & Jumlah & $\begin{array}{c}\text { Persentase } \\
(\%)\end{array}$ \\
\hline 1 & Sangat Baik & 10 & $59 \%$ \\
\hline 2 & Baik & 6 & $35 \%$ \\
\hline 3 & Cukup & 1 & $6 \%$ \\
\hline 4 & Kurang & 0 & $0 \%$ \\
\hline & Jumlah & $\mathbf{1 7}$ & $\mathbf{1 0 0 \%}$ \\
\hline
\end{tabular}

Berdasarkan tabel 6 di atas bahwa hasil observasi dari 17 aspek penilaian kegiatan siswa pada siklus I, terdapat 10 aspek memperoleh kriteria sangat baik, 6 aspek memperoleh kriteria baik, 1 aspek memperoleh kriteria cukup dan tidak ada aspek yang memperoleh kriteria kurang.

Selain data observasi untuk mengamati kegiatan guru dan siswa pada proses pembelajaran, adapun data dalam mengukur keaktifan siswa saat proses pembelajaran berlangsung yang disajikan dalam tabel aktivitas belajar siswa;

Tabel 7 Analisis Aktivitas Belajar Siswa Siklus II

\begin{tabular}{|c|c|c|c|}
\hline \multirow{2}{*}{ No. } & \multirow[b]{2}{*}{$\begin{array}{c}\text { Kriteria } \\
\text { Aspek }\end{array}$} & \multicolumn{2}{|c|}{ Penilaian } \\
\hline & & Jumlah & $\begin{array}{c}\text { Persentase } \\
(\%)\end{array}$ \\
\hline 1 & Sangat Aktif & 13 & $41 \%$ \\
\hline 2 & Aktif & 15 & $47 \%$ \\
\hline 3 & Cukup Aktif & 4 & $12 \%$ \\
\hline 4 & Kurang Aktif & 0 & $0 \%$ \\
\hline $\mathbf{J u}$ & mlah Siswa & 32 & $100 \%$ \\
\hline
\end{tabular}




\section{Volume : 6 \\ Nomor : 4 \\ Bulan : November \\ Tahun : 2020}

\section{E-ISSH: 2656-940X \\ P-ISSH: 2442-367K \\ URL: jurnal.ideaspublishing.co.id}

Berdasarkan tabel 7 di atas terlihat bahwa dari 32 siswa yang diamati pada siklus II dinilai dari 4 indikator penilaian aktivitas belajar siswa mulai dari kerja sama, keaktifan, sikap menghargai pendapat teman, dan tanggung jawab sebanyak 13 siswa memperoleh kriteria sangat aktif, 15 siswa termasuk kriteria aktif, 4 siswa memperoleh kriteria cukup aktif dan tidak ada siswa yang memperoleh kriteria kurang aktif. Data tersebut menunjukkan bahwa aktivitas belajar siswa mengalami peningkatan sebesar $16 \%$ yaitu dari tindakan pada siklus I sebesar 72\% menjadi 88\% setelah dilakukan siklus II. Berdasarkan indikator kerja, persentase tersebut telah melebihi target yang diharapkan $85 \%$ sehingga penelitian dapat diakhiri dengan 2 siklus, siklus I, dan siklus II.

Berdasarkan data aktivitas belajar di atas bahwa keaktifan siswa dalam proses pembelajaran mengalami peningkatan dan telah meningkatkan hasil belajar siswa pula. Adapun data hasil belajar siswa pada siklus II sebagai berikut.

Tabel 8 Analisis Hasil Belajar Siswa Siklus II

\begin{tabular}{|c|c|c|c|}
\hline \multirow{2}{*}{ Nilai } & \multirow{2}{*}{$\begin{array}{c}\text { Kriteria } \\
\text { Aspek }\end{array}$} & \multicolumn{2}{|c|}{ Penilaian } \\
\cline { 3 - 4 } & Jumlah & $\begin{array}{c}\text { Persentase } \\
(\%)\end{array}$ \\
\hline$\leq 75$ & Tidak Tuntas & 4 & $12 \%$ \\
\hline$\geq 75$ & Tuntas & 28 & $88 \%$ \\
\hline Jumlah Siswa & $\mathbf{3 2}$ & $\mathbf{1 0 0 \%}$ \\
\hline
\end{tabular}

Berdasarkan tabel 8 di atas menunjukkan bahwa hasil belajar pada siklus I mengalami peningkatan sebesar $13 \%$ yaitu dari siklus I $75 \%$ menjadi $88 \%$ setelah pelaksanaan tindakan pengajaran pada siklus II. Berdasarkan indikator kerja, persentase tersebut telah mencapai target yang diharapkan yaitu $85 \%$.

Pada tahap releksi permasalahan yang ditemukan pada pelaksanaan siklus I sebagian besar telah diperbaiki pada siklus II. Data hasil penelitian siklus II menunjukkan bahwa indikator kerja telah tercapai yaitu $85 \%$. Sehingga penelitian tindakan kelas ini dapat diakhiri dengan 2 siklus yaitu siklus I dan siklus II.

\section{Pembahasan}

Penelitian ini dilaksanakan dengan 2 siklus melalui penggunaan model pembelajaran kooperatif tipe two stay two stray dalam pelaksanaan tindakan pengajaran pada siklus I dan II. Berdasarkan hasil analisis data yang dilakukan, menjawab rumusan masalah penelitian ini yaitu, hasil observasi kegiatan guru pada siklus I bahwa dari 19 aspek penentu kegiatan guru 
terdapat 8 aspek atau sebesar $42 \%$ yang memperoleh kriteria sangat baik, 6 aspek atau sebesar $31 \%$ memperoleh kriteria baik, 3 aspek atau 16\% memperoleh kriteria cukup dan aspek yang memperoleh kriteria kurang berjumlah 2 aspek atau sebesar 11\%. Sedangkan pada observasi kegiatan siswa dari 16 penentu kegiatan siswa, 7 aspek atau $44 \%$ memperoleh kriteria sangat baik, 6 aspek atau 38\% memperoleh kriteria baik, 1 aspek atau 6\% memperoleh kriteria cukup, dan 2 aspek atau 12\% yang memperoleh kriteria kurang.

Pada siklus II hasil observasi kegiatan guru mengalami peningkatan pada masingmasing kriteria penilaian yaitu aspek yang memperoleh kriteria sangat baik meningkat menjadi 11 aspek atau sebesar 55\%, 7 aspek atau sebesar 35\% yang memperoleh kriteria baik, 2 aspek atau $10 \%$ yang memperoleh kriteria cukup, dan aspek yang memperoleh kriteria kurang berjumlah 0 aspek atau tidak ada aspek yang termasuk dalam kriteria kurang. Sedangkan hasil observasi kegiatan siswa dari 16 penentu kegiatan siswa meningkat menjadi 10 aspek atau 59\% yang memperoleh kriteria sangat baik, 6 aspek atau 38\% memperoleh kriteria baik, 1 aspek atau 6\% memperoleh kriteria cukup, dan aspek yang memperoleh kriteria kurang menurun menjadi 0. Tidak ada aspek yang masuk dalam kriteria kurang. Hal ini membuktikan bahwa perhatian siswa sebagian besar sudah berpusat pada pencapaian tujuan pembelajaran.

Berikut ini diagram yang menggambarkan peningkatan kegiatan guru dan kegiatan siswa.

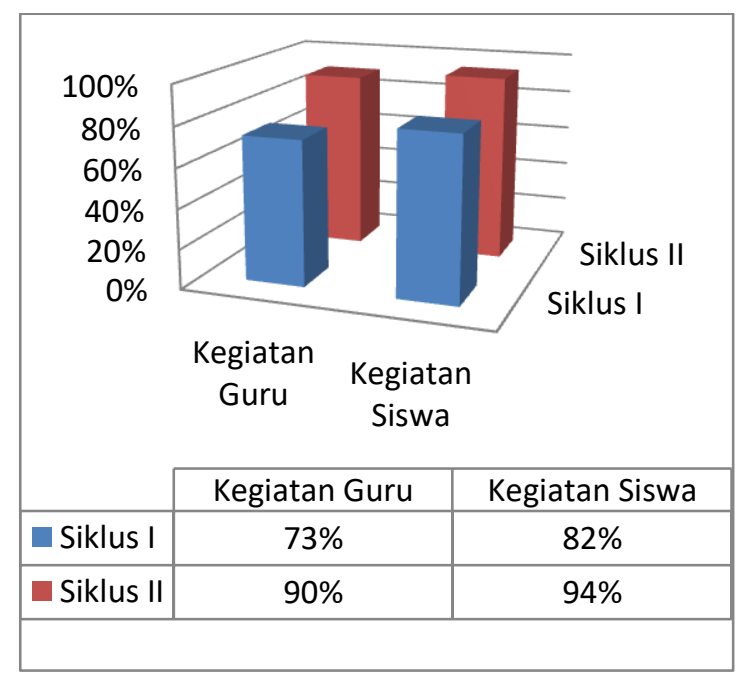

Gambar 1 Diagram Peningkatan Kegiatan Guru dan Siswa dari Siklus I ke Siklus II

Adapun dari segi keaktifan siswa dalam pembelajaran, data menunjukkan adanya peningkatan pada kategori sangat aktif dan aktif dengan masing-masing persentase $34 \%$ dan $38 \%$ (tabel 4.3) siklus I meningkat menjadi $41 \%$ kriteria sangat aktif dan $47 \%$ kriteria aktif 
Volume : 6

Nomor : 4

Bulan : November

Tahun : 2020

(tabel 4.7) pada siklus II. Keaktifan siswa tersebut diolah dari indikator penilaian aktivitas belajar siswa yang terdiri dari kerja sama, keaktifan, sikap menghargai pendapat teman, dan tanggung jawab.

Berikut ini diagram yang menggambarkan peningkatan aktivitas belajar.

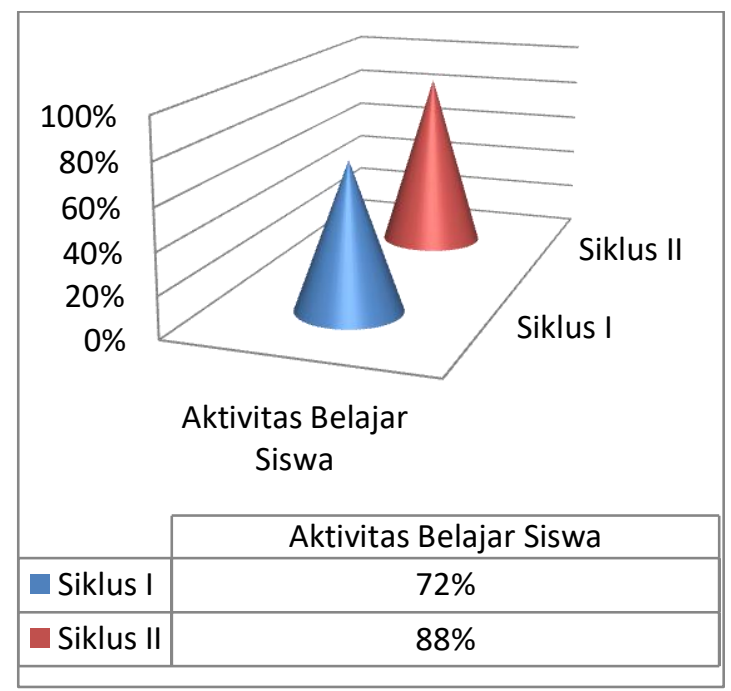

Gambar 2 Diagram Peningkatan Aktivitas Belajar Siswa dari Siklus I ke Siklus II

Sedangkan dari segi ketuntasan belajar, data hasil belajar yang telah diolah dan adanya peningkatan dengan persentase $75 \%$ (tabel 4.4) pada siklus I, meningkat menjadi $88 \%$ pada siklus II (tabel 4.8). Hal ini diikuti penurunan pada kriteria tidak tuntas sebesar $25 \%$ pada siklus I (tabel 4.4) menjadi 12\% pada siklus II (tabel 4.8). Ketuntasan belajar tersebut diolah dari data hasil belajar siswa yang terdiri dari aspek afektif, kognitif, dan psikomotorik.

Penilaian aspek afektif terdiri dari beberapa kriteria yaitu sopan, jujur, peduli, dan disiplin. Sedangkan penilaian aspek kognitif peneliti memberikan soal 6 nomor pada masingmasing siklus dan pada aspek psikomotorik peneliti menggunakan pedoman dengan beberapa kriteria yang harus dipenuhi dalam kegiatan diskusi kelompok yaitu penguasaan materi diskusi, kemampuan menjawab pertanyaan, kemampuan mengolah kata, dan kemampuan menyelesaikan masalah. Hasil belajar yang telah diolah dan dianalis dengan menggunakan ketiga aspek tersebut menunjukkan adanya peningkatan dari siklus I ke siklus II. Oleh karena itu, dibuatkan diagram yang menggambarkan peningkatan dari masing-masing aspek dari siklus I ke siklus II. 
P-ISSH: 2656-940X

URL: jurnal.ideaspublishing.co.id
Volume : 6

Nomor : 4

Bulan : November

Tahun : 2020

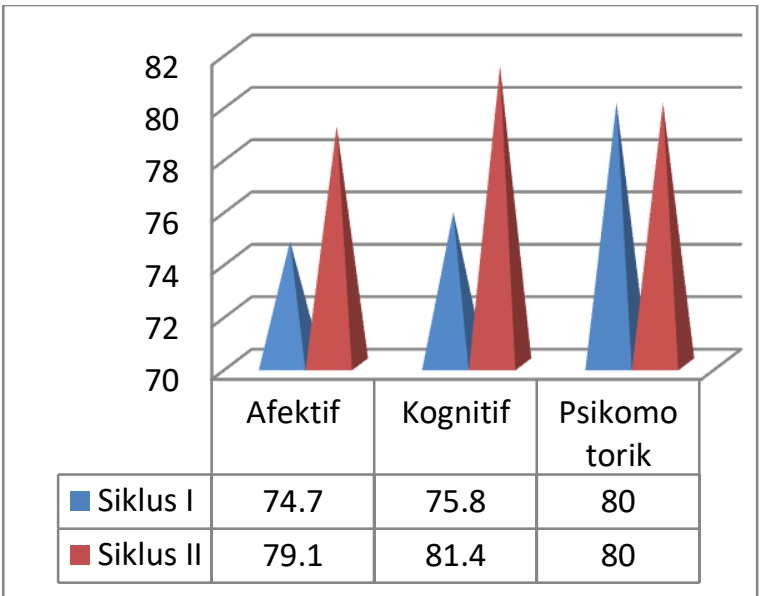

Gambar 3 Diagram Rata-rata Peningkatan Masing-masing Aspek Hasil Belajar Siswa dari Siklus I ke Siklus II

Berdasarkan diagram 3 di atas bahwa rata-rata perolehan nilai untuk masing-masing aspek dari siklus I ke siklus II. Pada siklus I aspek afektif, kognitif, dan psikomotorik memperoleh rata-rata 74.7, 75.8, dan 80 sedangkan pada siklus II masing-masing aspek memperoleh rata-rata 79.1, 81.4, dan 80. Diagram 3 di atas juga menunjukkan bahwa aspek afektif dan kognitif mengalami peningkatan yang signifikan, sedangkan aspek psikomotorik tidak menunjukkan adanya peningkatan ataupun penurunan artinya masih tetap sama dengan siklus I.

Adanya peningkatan pada aspek hasil belajar, maka perlu dibuat juga diagram rata-rata peningkatan hasil belajar siswa yang tuntas dan tidak tuntas yang diukur dari ketiga aspek di atas.

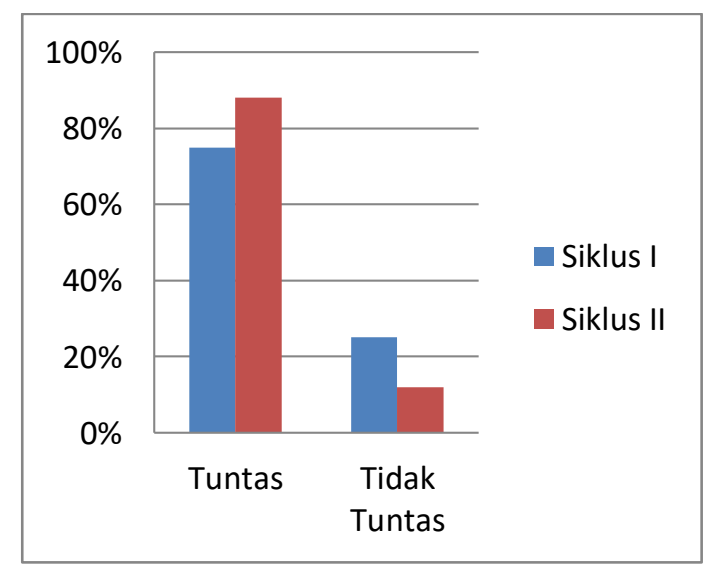

Gambar Diagram 4 Rata-rata Peningkatan Hasil Belajar Siswa dari Siklus I ke Siklus II

Berdasarkan diagram di atas, siswa yang memperoleh nilai $\geq 75$ (tuntas) sebesar $75 \%$ atau sebanyak 24 siswa pada siklus I, kemudian pada siklus II meningkat menjadi $88 \%$ atau sebanyak 28 siswa yang tuntas. Sedangkan yang memperoleh nilai $\leq 75$ (tidak tuntas) pada 


\section{Volume : 6 \\ Nomor : 4 \\ Bulan : November \\ Tahun : 2020}

E-ISSH: 2656-940X

P-ISSH: 2442-367K

URL: jurnal.ideaspublishing.co.id

siklus I sebesar $25 \%$ atau sebanyak 8 siswa, menurun menjadi $12 \%$ atau sebanyak 4 siswa pada siklus II. Dengan demikian, peningkatan hasil belajar siswa dari siklus I ke siklus II yaitu sebesar $13 \%$ atau sebanyak 4 siswa yang tuntas atau memperoleh nilai $\geq 75$.

\section{Simpulan}

Berdasarkan hasil penelitian dan pembahasan pada penelitian tindakan kelas ini, maka dapat disimpulkan bahwa aktivitas belajar siswa meningkat berdasarkan hasil analisis aktivitas belajar siswa selama proses pembelajaran. Berdasarkan data tersebut menunjukkan adanya peningkatan persentase. Skor Aktivitas belajar siswa dari jumlah 32 siswa, pada observasi awal terdapat 8 siswa (25\%) yang memperoleh kriteria sangat aktif dan aktif, meningkat menjadi 23 siswa (72\%) pada siklus I dan pada siklus II meningkat menjadi 28 siswa (88\%). Berdasarkan data tersebut dapat disimpulkan bahwa sebagian besar siswa memiliki aktivitas yang tinggi setelah tindakan pengajaran dengan model pembelajaran two stay two stray.

Meningkatnya hasil belajar siswa dibuktikan berdasarkan data hasil evaluasi di akhir pembelajaran dengan jumlah 6 butir soal yang memuat materi-materi yang telah dipelajari yaitu APBN dan APBD. Diperoleh hasil belajar dari 32 siswa dengan jumlah siswa yang tuntas atau memperoleh nilai minimal 75 pada observasi awal berjumlah 9 siswa dengan persentase $28 \%$, meningkat menjadi $75 \%$ atau sebanyak 24 siswa pada siklus I dan $88 \%$ atau sebanyak 28 siswa pada siklus II. Berdasarkan data hasil belajar tersebut, maka sebagian besar siswa mampu mencapai nilai KKM yaitu 75.

\section{Daftar Pustaka}

Arikunto, Suharsimi. (2012). Prosedur Penelitian Suatu Pendekatan Praktek. Jakarta: Rineka Cipta.

Berdiati, Ika. (2010). Pembelajaran Bahasa Indonesia Berbasis PAKEM (Pembelajaran Aktif, Kreatif, Efektif dan Menyenangkan). Bandung: Sega Arsy.

Buchari, Alma. (2009). Guru Profesional (Menguasai Metode dan Terampil Mengajar). Bandung: Alfabeta.

Hamalik, Oemar. 2009. Kurikulum dan Pembelajaran. Jakarta: Bumi Aksara.

Kunandar. (2014). Penilaian Autentik (Penilaian Hasil Belajar Peserta Didik Berdasarkan Kurikulum 2013). Jakarta: Raja Grafindo Persada.

Kunandar. (2016). Langkah Mudah Penelitian Tindakan Kelas Sebagai Pengembangan Profesi Guru. Jakarta: PT. Raja Grafindo Persada.

Nasution, S. (2012). Didaktik Asas Mengajar. Jakarta: Bumi Aksara 


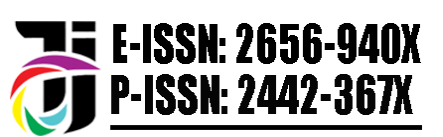

URL: jurnal.ideaspublishing.co.id
Volume : 6

Nomor : 4

Bulan : November

Tahun : 2020

Permendibud. (2015). Undang-undang No. 53 Tahun 2015 Tentang Penilaian Hasil Belajar Oleh Pendidik dan Satuan Pendidikan Pada Pendidikan Dasar dan Pendidikan Menengah. Jakarta: Permendibud.

Sardiman, A. M. (2012). Interaksi dan Motivasi Belajar Mengajar. Jakarta: Rajawali Press.

Shoimin. (2015). Model Pembelajaran Inovatif dalam Kurikulum 2013. Yogyakarta: Ar-Ruzz Media.

Sudjana, Nana. (2012). Penelitian Hasil Proses Belajar Mengajar. Bandung: Remaja Rosda Karya.

Sudjana. (2013). Dasar-dasar Proses Belajar Mengajar. Bandung: Sinar Baru. Algen sindo. Suprijono, Agus. (2012). Metode dan Model-Model Mengajar. Jakarta: PT. Bumi Aksara.

Suprijono, Agus. (2013). Cooperatif Learning. Yogyakarta: Pustaka Pelajar.

Syamsudin M, Abin. (2003). Psikologi Pendidikan. Bandung: Remaja Rosda Karya.

Vivien. (2012). http://vivienanjadi.blogspot.co.id/2012/modelpembelajaran-kooperatif.html diakses pada tanggal 13 Mei 2015. 